\title{
ЛЕКСЕМИ «ВІДБИВАТИ» І «ДОЗВОЛЯТИ» В ГАЗЕТНИХ МАТЕРІАЛАХ
}

\author{
Марія Ріпей \\ Львівський національний університет імені Івана Франка, \\ вул. Генерала Чупринки, 49, 79044, Львів, Україна, \\ e-mail: maria-kr@ukr.net
}

Проаналізовано вживання дієслів «відбивати» і «дозволяти» у журналістських текстах. Зосереджено увагу на поясненні значень цих слів у тлумачних словниках сучасної української мови. Приклади наведено із щоденної всеукраїнської газети «День».

Ключові слова: лексема, ненормативне вживання, газетні матеріали, словники.

Загальна проблема та ї̈ науково-практична иінність. Журналістське слово повинно бути продуманим, доречним, точним. Особливої уваги потребує газетна мова, «друкована продукція повинна насамперед популяризувати національну мову, а отже, дотримуватися її норм та підвищувати рівень мовної культури населення» [14]. Адже «працівники 3МІ повинні забезпечити правильність поданої інформації не тільки в аспекті змісту повідомлення, але і з точки зору відповідності медіа-тексту чинним мовним нормам» [15].

Аналіз досліджень $і$ публікащій. На мовленнєвих неточностях акцентують у своїх працях Б. Антоненко-Давидович, І. Вихованець, М. Волощак, К. Городенська, П. Дудик, А. Капелюшний, А. Коваль, Н. Непийвода, О. Пономарів, О. Сербенська, М. Яцимірська та ін. Зокрема, Б. Антоненко-Давидович звертає увагу на слова, «потрібні для точного відтворення думки, слова, що поширюють наші мовні можливості» [1].

Ставили за мету на підставі довідкової літератури і власного редакторського досвіду проаналізувати приклади вживання дієслів «відбивати» і «дозволяти» у газетних публікаціях.

Аналізований фактаж дібрано із щоденної всеукраїнської газети «День».

Виклад матеріалу. Як видно із журналістських текстів, є труднощі у вживанні лексеми «відбивати». Наприклад, читаємо: «Все, що відбувається в країні, прямо чи опосередковано відбивається на житті кожного з нас» (14 лютого 2013 р.); «...Чому такий рівень виробництва ніяк не відбивається на нашому добробуті?» (14 лютого 2001 р.); «...ситуація на острові повною мірою відбивала поточну ситуацію в країні...» (28 серпня 2009 р.); «...ця премія, як ніяка інша, відбиває певне глобальне соціальне замовлення, затребуваність визначеної теми» (26 квітня 2001 р.); «Малопомітне уповільнення темпів зростання цін відбиває сезонну циклічність...» (13 вересня 2011 р.);

(C) Ріпей М., 2018 
«Будь-який договір... має відбивати інтереси обох сторін і бути збалансованим...» (24 червня 2016 р.); «Трагічна історія... відбиває духовні проблеми сучасної людини, іiї взаємини зі світом...» (14 січня 2015 р.); «Музей має відбивати не лише трагедію Голокосту...» (7 березня 2012 р.); «відбивати реальність...» (30 черня 2017 р.); «Це відбивається і на системі парламентаризму» (20 квітня 2007 р.); «циркулярна міграція» відбиває посилену зовнішню мобільність людей» (1 березня 2011 р.); «все це відбивається на груповій поведінці мешканців і прийнятті ними рішень» (8 серпня 2017 р.).

Можливо, це пов'язано з тим, що у словниках чітко не розмежовано значення цього слова. У тритомному російсько-українському словнику наведено такі відповідники до російського слова «отражать»: «1. (удар, нападение) відбивати... 2. (возражение, нападки и т. п.) відбивати... 3. (отбрасывать в обратном направлении) відбивати, редко відкидати... 4. (воспроизводить, передавать что-либо) відбивати, відображати...» [10: 2: 406]. «Русско-украинский словарь синонимов» подає такі українські відповідники до слова «отразить» (изобразить в произведениях искусства факты, события, явления, лица и т. п.)... відбити, відобразити, віддзеркалити» [11: 143]. А у словнику складної лексики Святослава Караванського серед українських відповідників до слів «отражать», «отражение» немає ні відображати, ні відображення [4: 36].

У «Великому тлумачному словнику сучасної української мови» (уклад. і голов. ред. В. Т. Бусел) слова «відбивати» і «відображати» подано як синоніми. Зокрема, друге значення слова «відображати» трактовано як «те саме, що віддзеркалювати, відбивати» [2: 175]. А у словниковій статті до слова «відбивати» зазначено, що у переносному значенні «виражати чиї-небудь внутрішні якості або властивості. // Вiдображати, виражати... Відтворювати, зображати, втілювати в образах життя, ідеї і т. ін.» [2: 164]. У цьому словнику також читаємо «крива лінія, яка відбиває зміни будь-якого показника» [2: 524]; «відбивається ставлення інших осіб до суб'єкта» [2: 631]; «сукупність... умов у даній місцевості, що відбиваються на якості... спостережень» [2: 44]; «план, що відбиває витрати коштів» [2: 105]; «галюцинації, що відбивають зміст емоційно забарвлених переживань» [2: 220]; «положення якої-небудь науки, що відбиває причинно-наслідковий зв'язок» [2: 397]; «лінія, що відбиває частоту серцевих скорочень» [2: 525]; «художній образ, який умовно відбиває яку-небудь думку, ідею, почуття і т. ін.» [2: 1315]; «сигнальний щит із світловими чи електромагнітними показниками, що відбивають стан контрольованого устаткування» [2: 1425]. I у «Словнику української мови» (у 20 томах) у словниковій статті лексеми «відбивати» також зазначено «перен. Виражати чиї-небудь внутрішні якості або властивості... Лікар посміхнувся приємною теплою посмішкою, щ⿻ відбивала його душевну врівноваженість і певність своїх дій... Відображати, виражати. Категорія «продуктивні сили» відбиває відносини між людиною і природою. Запорізька Січ відбивала прагнення українського народу визволитися від іноземних поневолювачів. Діалекти можуть відбивати особливості племінних мов... Відтворювати, зображати, втілювати в образах життя ідеї і т. ін. Словник української мови П. Білецького-Носенка відбиває украӥнську мову периої половини XIX ст...» [13: 2: 581]. Також подано «Істотною ознакою предмета називається та ознака, яка відбиває корінну, найбільш важливу властивість предмета» [13: 6: 620]. У «Великому тлумачному словнику сучасної української мови» (кер. вид. проекту П. М. Мовчан, В. В. Німчук, В. Й. Клічак) у словниковій статті лексеми «відбивати» наведено такі приклади: «Усмішка відбиває душевну врівноваженість, Відбивати дійсність у мистецтві, 
Своє відбиття у дзеркалі, Відбиття подиву в очах, Відбиття в свідомості об'єктивної дійсності» [3: 131].

Немає ніяких сумнівів щодо правильності вживання лексеми «відбити» у значеннях «ударами відокремлювати частину від цілого», «відкидати зустрічним ударом (м'яч, шаблю та ін.)», «ударами пошкодити що-небудь в організмі», «успішно протидіяти наступові супротивника, боєм змушувати його відступити», «відбирати кого-, що-небудь, повертати назад силою, боєм», «ударами, дзвоном позначати час (про годинник і т. ін.)»; «відбивати такт», «сікти, розм'якшувати м'ясо, б'ючи чим-небудь», «залишати на чому-небудь слід від чогось». Наприклад, «Майка відбивала іноді молотком від якоїсь скелі шматочок каменю й ховала собі в рюкзак»; «Староста взяв палицю, відбив роги з бика і подав дівчині в руки»; «Зачинили лавку і стали відбивати ящики» (Г. Квітка-Основ'яненко); «Злодій відбиває колодку» (М. Коцюбинський); «Бійці піднялися і йшли у вогонь і атаку ворожу відбили» (А. Головко) [12: 1: 553]. Однак у тих випадках, коли йдеться про вираження, відтворення, втілення в образах, правильно вживати «відображати» або «віддзеркалювати» $[5 ; 6]$. Наприклад, «Мужність, пильність, незламну стійкість радянських прикордонників, їхні високі моральні якості відображає фільм «Блакитна стріла»; «Артистові сцени потрібно... уміти вбирати в себе дійсний, реальний матеріал, щоб потім пройняти його вогнем своєї обдарованості і відобразити перед глядачем тип з усією характерною життєвою правдою»; «Семирічний план став кровною справою всього народу, бо він відображав його думи і сподівання»; «Староруське письменство... дуже обмежено відобразило сучасну йому живу мову» [12: 1: 613]; «ї̈і обличчя віддзеркалювало мажорний настрій батька...»; «Дружба народів віддзеркалює в собі дружбу двох великих культур» [12: 1: 579].

На нашу думку, у вищенаведених реченнях з газетних публікацій правильно так писати: «...відображається на житті...»; «...не відображається на нашому добробуті»; «...ситуація на острові... відображала... ситуацію в країні...»; «...премія... відображає певне... замовлення...»; «...уповільнення темпів зростання цін відображає сезонну циклічність...»; «...договір... має відображати інтереси обох сторін...»; «...історія... відображає (віддзеркалює) духовні проблеми... людини...»; «музей має відображати не лише трагедію...»; «відображати (віддзеркалювати) реальність...»; «... відображається і на системі парламентаризму»; «...міграція відображає... зовнішню мобільність людей»; «...відображається на груповій поведінці мешканців...».

Не завжди правильно журналісти вживають лексему «дозволяти». У газетних матеріалах читаємо: «Такий термін дозволить оцінити успішність проведення процедури...» (15 червня 2016 р.); «Газета дозволяє побачити наше завтра...» (4 червня 2015 р.); «Навіть тижневе маневрування, на його думку, дозволяє збільшити потужності атомних електростанцій на величину від 300 до 500 МВт» (18 жовтня 2016 р.); «Український стартап Senstone - пристрій, що дозволяє записувати голосові замітки та перетворювати їх у друкований текст...» (6 березня 2017 р.); «Телевізор - засіб розваги, що дозволяє мільйонам людей слухати один і той самий жарт в один і той самий час (16 листопада 2011 р.); «Усі студії оснащено найсучаснішим технічним обладнанням, що дозволяє мінімізувати використання живлення...» (6 жовтня 2016 р.); «Якщо людина регулярно проходить медогляд... це дозволяє своєчасно виявити хвороби» (4 лютого 2017 р.); «...знімок поверхні Марса... дозволяє побачити корінні породи на поверхні планети» (24 лютого 2017 р.); «...сенсор, який дозволяє... працювати в ніч- 
ний час...» (13 грудня 2017 р.); «...багато теорій і концепцій з області індивідуальної психології можна екстраполювати й на суспільні реалії, умовно замінюючи поняття «людина» на поняття «суспільство». Це дозволяє подивитися на наше громадське i політичне життя під новим кутом...» (19 лютого 2018 р.).

I у «Словнику української мови» (у 20 томах) у словниковій статті лексеми «дозволяти» наведено «...Давати можливість що-небудь робити (про стан, умови, обставини і т. ін.). Потім він доносив князеві, щяо полишав службу через те, щчо літа й здоров'я не дозволяють йому клополтатися такими трудними справами. Справді, вдалині, як тільки дозволяло бачити бліде місячне сяйво, наближався хтось верхи. Піп гречно, наскільки дозволяла йому повнота, вклонився Варварі» [13: 4: 344]. У «Великому тлумачному словнику сучасної української мови» (кер. вид. проекту П. М. Мовчан, В. В. Німчук, В. Й. Клічак) зазначено «Літа й здоров’я не дозволяють йому працюювати» [3: 243]. У «Великому тлумачному словнику сучасної української мови» (уклад. і голов. ред. В. Т. Бусел) подано «програма граматичного розбору, яка дозволяє визначити призначення елементів речовини» [2: 28]; «прилад, який дозволяє відтворювати основні рухи нижньої щелепи» [2: 41]; «закріплений велосипед або апарат із педалями, що дозволяє дозувати м'язову роботу і реєструвати відповідну реакцію організму» [2: 120]; «огорожа з дроту, крізь який короткочасно пропускається слабкий електричний струм, що дозволяє утримувати худобу на певній території» [2: 346]; «вид телезв'язку, що дозволяє абонентам чути і бачити один одного» [2: 169]; «сонячні дні, що дозволяють провести в південних районах ранні сільськогосподарські роботи» [2: 187]; «реєстрація електричних явищ серця, що дозволяє наочно відобразити ритм серцевої діяльності» [2: 525]; «радіопередавач, який при. проковтуванні людиною або твариною дозволяє реєструвати різні прояви діяльності шлунково-кишкового тракту» [2: 1197]; «про... телекамеру, яка дозволяє бачити об'єкти, недоступні для безпосереднього спостереження» [2: 1437]; «великий термос, що дозволяє тривалий час зберігати температуру вміщених в нього продуктів харчування» [2: 1445]; «пояснювати свої вчинки, дії, наводити причини, які... дозволяють вибачити» [2: 146].

У російсько-українському словнику читаємо, що російською мовою «предоставить возможность» - українською «дати можливість, дозволити» [10: 2: 817], російською «предоставить решение вопроса кому» - українською «полишити розв'язання питання на кого, дозволити (дати змогу, дати право) розв’язати питання кому» [10: 2: 817-818]. Тож можемо стверджувати, що цей словник «дозволяти», «давати змогу» i «давати можливість» подає як синоніми.

Хоча у російсько-українському словнику складної лексики зазначено, що російською мовою «предоставлять возможность»- українською «давати змогу» [4: 450], російською «разрешать» - українською «давати дозвіл, не забороняти, допускати» [4: 523].

Вживання лексеми «дозволяти» у вищенаведених реченнях з газетних публікацій кваліфікуємо як помилку. Бо «дозволяти» - це «давати згоду, дозвіл, право на здійснення чого-небудь». Наприклад, «Він дозволяв ворожкам робити з жінкою, що їм забагнеться, аби звести її на ноги» (М. Коцюбинський); «Пройти до нього в палату дозволяли тільки комусь одному з його товаришів»; «Артем своїй Любі такого поводження не міг би дозволити»; «Чи не забагато ви дозволяєте собі, сеньйоре?», «Я 
тільки дозволила собі викреслити олівцем одну фразу» (Леся Українка); «Дозволь мені, мати, Дівчину взяти, Що у неї русі коси Аж по самі п’яти» [12: 2: 347].

А у значенні «давати можливість що-небудь робити (про стан, умови, обставини і т. ін.)» варто вживати не «дозволяти», як зазначено у «Словнику української мови» (у 20 томах) [13: 4: 344], у «Великому тлумачному словнику сучасної української мови» (уклад. і голов. ред. В. Т. Бусел) [2: 312], у «Великому тлумачному словнику сучасної української мови» (кер. вид. проекту П. М. Мовчан, В. В. Німчук, В. Й. Клічак) [3: 243], а «давати змогу», «давати можливість» [6-9]. Наприклад, «Він все ще надіявся, що всі скоро заснуть і запанує те сонне царство, яке дасть йому можливість вийти з хати на побачення (Г. Тютюнник)»; «Отримала я вашого листа вчора і хотіла в той же день відповісти, але не було можливості» (Леся Українка) [12: 4: 778]. Бо можна дозволити щось зробити, але не дати змоги це зробити. Наприклад, дозволити вийти з аудиторії, але не дати змоги вийти (не дати пройти або замкнути двері). Правильне вживання цих слів, на нашу думку, добре ілюструє приклад переходу вулиці, де $є$ світлофор. Зелене світло світлофора дозволяє пройти, а машини зупиняються, даючи змогу пройти.

Неправильно писати «...термін дозволить оцінити...»; «газета дозволяє побачити...»; «...маневрування... дозволяе збільшити потужності... »; «...пристрій, що дозволяє записувати голосові замітки...»; «телевізор... дозволяє мільйонам людей слухати один і той самий жарт в один і той самий час; «...обладнання, що дозволяє мінімізувати використання живлення...»; «...медогляд... дозволяє своєчасно виявити хвороби»; «...знімок поверхні Марса... дозволяє побачити корінні породи....»; «... сенсор, який дозволяє... працювати в нічний час...»; «...багато теорій і концепцій... можна екстраполювати й на суспільні реалії... Це дозволяє подивитися на наше... життя під новим кутом...». У цих випадках правильно замість «дозволяють» («дозволяє») вживати «дають (дає) змогу» або «дають (дає) можливість».

Однак у реченні «Лише на свята в музеї дозволяють доторкнутися руками до експонатів...» (16 січня 2014 р.) слово «дозволяють» вжито правильно. Бо на те, щоб «доторкнутися руками до експонатів», $є$ дозвіл, очевидно, офіційне розпорядження.

Висновки. Отже, можемо підсумувати:

1. Коли йдеться про вираження, відтворення, втілення в образах, правильно вживати слово «відображати», бо «образ», «зображення», «відображення» (або «віддзеркалювати»), але не лексему «відбивати»;

2. У значенні «давати згоду, дозвіл, право на здійснення чого-небудь» правильно вживати «дозволяти», а у значенні «давати можливість що-небудь робити (про стан, умови, обставини та ін.)» - «давати змогу», «давати можливість».

\section{REFERENCES}

1. Антоненко-Давидович Б. Як ми говоримо. Київ: Либідь, 1991. С. 31.

2. Великий тлумачний словник сучасної української мови (з дод. допов. та $\mathrm{CD}$ ) / уклад. і голов. ред. В. Т. Бусел. Київ; Ірпінь: ВТФ «Перун», 2007. 1735 с.

3. Великий тлумачний словник сучасної української мови / кер. вид. проекту П. М. Мовчан, В. В. Німчук, В. Й. Клічак. Київ: Вид-во «Дніпро», 2009. 1332 с.

4. Караванський С. Російсько-український словник складної лексики. Київ: ВЦ «Академія», 1998. 712 с. 
5. Ріпей М. Мовленнєві неточності на сторінках газет. Вісник Львівського університету. Сер. Журналістика. 2007. Вип. 30. С. 288-293.

6. Ріпей М. В. Аспекти ненормативного вживання дієслів у газетних матеріалах. Мова, суспільство, журналістика (за матеріалами XIV міжнар. наук.-практ. конф., м. Київ, 18 квіт. 2008 р.). Київ, 2009. С. 214-217.

7. Ріпей М. В. Порушення лексичної норми на сторінках газет. Культура народов Причерноморья. Симферополь, 2007. № 101. С. 107-110.

8. Ріпей М. Редакторська правка науково-технічного тексту. Украӥнська мова. 2014. № 2. С. 61-67.

9. Рипей М. В. Редакторская правка газетного текста на украинском языке. Вестник НГУ. Сер. История, филология. 2013. Т. 12, вып. 10. Журналистика. С. 118-122.

10. Русско-украинский словарь: в 3 т. 2-е изд. Київ: Голов. ред. Укр. Рад. Енциклопедіï, 1980-1981.

11. Русско-украинский словарь синонимов / Н. П. Башнякова, Г. П. Вишневская, Н.Н. Пилинский и др.; под ред. Н. Н. Пилинского. Киев, 1995. С. 143.

12. Словник української мови: в 11 т. Київ: Наук. думка, 1971-1980.

13. Словник української мови: у 20 т. Київ: Наук. думка, 2012-2015. Т. 2-6.

14. Супрун Л. В. Нормативність мовлення як складник мовної комунікації журналіста. Наукові записки Інституту журналістики. Київ, 2008. Т. 33. С. 47. URL: http:// journlib.univ.kiev.ua

15. Яворський А. Ю. Мовні помилки в журналістських текстах (на матеріалі одного номера газети «День»). Науковий вісник Волинського начіонального університету імені Лесі Украӥнки. Філологічні науки. Мовознавство. 2011. № 1. URL: http:// esnuir.eenu.edu.ua 


\title{
LEXEMES «TO BEAT» AND «TO LET» IN NEWSPAPERS
}

\author{
Mariya Ripey \\ Ivan Franko National University of Lviv, \\ Generala Chuprynky Str. 49, 79044, Lviv, Ukraine \\ e-mail: maria-kr@ukr.net
}

In this article authors take into consideration usage of the verbs «to beat» and «to let» in journalistic materials on the basis of reference literature and their own editorial experience. The article focuses on explanation of the meaning of these words in «A great Ukraine dictionary of the modern usage» (compiler and main editor W. T. Busel) and in «Ukraine language dictionary» (in twenty tomes). Materials for analysis are selected from «The Day» newspaper. «Russian-Ukrainian dictionary in three tomes», «Russian-Ukrainian dictionary of synonyms», «Russian-Ukrainian dictionary of complex vocabulary» by S. Caravansky and «A great Ukraine dictionary of the modern usage» (executives of the publishing project P. M. Movchan, V. V. Nimchuk, V. J. Klichak) were used for analysis. Examples are provided with Ukrainian dictionary in eleven tomes.

The main accent is concentrated on the inaccurate writing of the following phrases «to reflect on life», «to reflect on commonweal», «a deceleration of price growth reflects seasonal circle», «an agreement must reflect both parties' interests», «history reflects spiritual problems of modern person», «to reflect reality», «the term allows to sum up», «a newspaper allows to see», «a TV allows millions of people to listen to the exact same joke at the exact same time», «the equipment which allows to minimize power supply usage», «health check allows to detect diseases».

The conclusion proves that it is correct to use word «to reflect» which originates from the word «reflection» talking about expression, reproduction, impersonation. As well, it is correct to use the word «to allow» talking about the phrases «to agree», «to give permission to do something» which mean «to let somebody do something»..

Key words: lexemes, inappropriate usage, newspaper materials, dictionaries. 